\title{
The Relationship Between Board Interlocking and Income Smoothing Practices*
}

Flávio Ribeiro

Universidade Federal do Paraná, Departamento de Ciências Contábeis, Curitiba, PR, Brazil

Romualdo Douglas Colauto

Universidade Federal do Paraná, Departamento de Ciências Contábeis, Curitiba, PR, Brazil

Received on 11.10.2014 - Desk Acceptance on 12.28.2014 - $3^{\text {rd }}$ version accepted on 08.19.2015

\begin{abstract}
This study aims to investigate the influence of board interlocking in income smoothing practices in public companies with shares traded on the BM\&FBOVESPA. To achieve this objective we adopted a sample comprised of 58 Brazilian companies included in the Bovespa index. The study is classified as empirical and analytical and uses as a proxy for income smoothing a metric called the "smoothing factor" (SF), obtained through the factor analysis technique using the metrics $\mathrm{EM}_{1}$ and $\mathrm{EM}_{3}$ from Leuz, Nanda and Wysocki (2003). As independent variables we employed indicators of social network analysis. From a theoretical point of view, the study is relevant and innovates in making the connection between the resource dependence theory, the agency theory and board interlocking. In practical terms, the study shows the effects of the constitutive elements of corporate social networks, arising from the board interlocking structure, on income smoothing accounting practices. Regression with panel data using fixed effects showed that the constituent elements of corporate social networks tend to influence the practice of smoothing in the sample used. The results of the study show that companies that share board members with other organizations which smooth their results tend to adopt this organizational practice more easily; which can be explained by: (i) companies causing variations in performance due to operational decisions or financial reporting choices; and (ii) managers making use of discretionary practices in the reporting of profits.
\end{abstract}

Keywords: board interlocking, income smoothing, social network analysis. 


\section{INTRODUCTION}

The agency theory (Fama \& Jensen, 1983) and the resource dependence theory (Pfeffer, 1972; Johnson, Daily \& Ellstrand, 1996) are theories that form the basis for studies concerning boards of directors. The agency theory assigns to the board of directors the role of controlling and monitoring the decisions taken by managers, in an attempt to minimize conflicts of interest between different parts of an organization (Fama \& Jensen, 1983). The resource dependence theory helps in understanding boards of directors as facilitating mechanisms for accessing financial resources from outside an organization.

Although the majority of studies concerning boards of directors involve the agency theory (Hillman \& Dalziel, 2003), the complexity of corporate environments limits the practical application of this theory, since it is only able to explain some of the social phenomena related to boards of directors (Eisenhardt, 1989). Faced with this theorical shortcoming, the resource dependence theory highlights the importance of boards of directors in reducing uncertainties in the corporate environment. Links with other companies allow board members to make use of their personal reputations in order to obtain the external resources that are necessary for company development (Pfeffer, 1972; Pfeffer \& Salancik, 1978).

The participation of members of boards of directors in more than one corporation characterizes the phenomenon known as board interlocking (Knowles, 1973). Board interlocking encompasses, along with board members, directors responsible for links between companies (Mizruchi, 1996). Such ties are considered important in an organizational context (Fontes Filho, 2012), as it is thanks to these that companies are able to gain better access to commercial partners and can gain specific and strategic knowledge concerning particular companies (Gales \& Kesner, 1994). International studies (Davis, 1991; Haunschild, 1993; Haunschild \& Beckman, 1998) show that board interlocking is also considered an organizational information channel that influences in the adoption of certain corporative practices. The logic is that companies are more inclined to adopt such organizational practices when they repeatedly share board members with other strategically-aligned companies. Connelly and Slyke (2012) found that, in the same way that board interlocking influences in the adoption of constructive and positive practices, it can also lead to the spread of discretionary practices that aim to cause the smoothing of financial results.

In the Brazilian stock market income smoothing has frequently been the subject of scientific studies. Many of these endeavor to explain the practice of smoothing via different constructs: ADRs (Lopes \& Tukamoto, 2007); risk and return (Martinez \& Castro, 2008); cost of third-party capital and capital structure (Castro \& Martinez, 2009); levels of corporate governance (Lyra \& Moreira, 2011); accounting conservatism (Almeida, Sarlo Neto, Bastianello, \& Adoneque, 2012); and ratings agency classifications (Tonin, 2012).

With the aim of expanding the horizons of scientific knowledge regarding income smoothing practices, this study proposes to investigate the relationship between such practices and the constitutive elements of corporate social networks originating from the board interlocking structure. The objective is to address the following issue: What is the influence of board interlocking on income smoothing practices in publicly traded companies listed on the BM\&FBOVESPA? The study covers the years from 2009 to 2014. The underlying hypothesis is that the constitutive elements of corporate social networks, represented by degree centrality, betweenness centrality, information centrality, size of board, and outsiders, tend to have a positive influence in the practice of income smoothing.

The study helps to address shortcomings related to understanding organizational aspects that tend to influence in the spreading of results management corporate practices. Specifically, it is considered that the existence of board interlocking favors the adoption of income smoothing practices related to (i) operational decisions and (ii) the adoption of discretionary practices in the reporting of profits. It should be mentioned that neither Brazilian nor international studies regarding the combination of these two issues (income smoothing and board interlocking) were found, thus allowing for the possibility of a fruitful discussion with a wide ranging theorical and empirical impact in the field of accounting for external users. Considering that the studies are still at an early stage, this paper uses as a proxy a metric called "smoothing factor" (SF), obtained via factor analysis, which groups together the metrics $\mathrm{EM}_{1}$ e EM from Leuz et al. (2003) to represent a single factor for analysis. This mathematical route also represents one of the methodological contributions of this paper.

\section{BOARD INTERLOCKING AND THE RESOURCE DEPENDENCE THEORY}

The expressions "board interlocking" (Santos \& Silveira, 2007; Mendes-da-Silva, 2010; Connelly \& Slyke, 2012; Mindzak, 2013), “interlocking directorship" (Zajac, 1988; Hung, 1998; Au, Peng, \& Wang, 2000), "board network" (Battiston, Weisbuch, \& Bonabeau, 2003; Kim, 2005), "director interlocks" (Haunschild \& Beckman,
1998), and "interlocking directorates" (Dooley, 1969; Ornstein, 1982) have all been used in financial literature to define links between companies via boards of directors.

Board interlocking refers to the social relationship created between two or more companies via the inclu- 
sion of the same professional on their respective boards of directors (Fich \& White, 2005). This professional can provide access to important resources that are essential to the company (Hung, 1998). In the United States, the participation of the same board member or executive in more than one company is quite common. Dooley (1969) found that, since the 1930s, 90\% of the largest American organizations had at least one board member working at more than one company. Davis (1991) discovered corporate ties in 40 American organizations in the 1980s. On average, board members acted in seven large corporations.

In Canada, board interlocking is considered a common phenomenon in the largest corporations. Ornstein (1982) found that, from 1946 to 1977, the 100 largest companies exhibited, approximately, 1600 corporate ties in the form of social networks. Au et al. (2000) identified board interlocking in around $61 \%$ of the 200 largest companies in Hong Kong, in 1997. This percentage was a little lower than those found in England (69\%) and in the United States (64\%), in the same period. Cox and Rogerson (1985) investigated the 115 largest companies in South Africa and found that in $50 \%$ of them there were board members acting in more than one organization.

Santos and Silveira (2007) examined 320 companies with liquidity on the Brazilian capital market, between 2003 and 2005, and the results indicated that 74\%, in 2003 , and $68.8 \%$, in 2005 , had constitutive corporate social network ties. Moreover, in 2005, 50\% of those professionals who acted as chairman of one board also simultaneously participated on the board of another company. Mendes-da-Silva (2010) studied 452 publicly traded companies, between 1997 and 2007, and showed that, on average, $60 \%$ of board members were connected to seven companies at the same time.

The main studies involving board interlocking are based on the resource dependence theory, which is used to explain the reasons for connections in established networks between companies (Hillman, Cannella, \& Paetzold, 2000). Pfeffer and Salancik (1978) state that when an organization appoints a professional onto its board of directors, it is expected that this board member provides resources that help the company to structure itself financially and to develop over time. They explain that an adoption of board interlocking provides various benefits to entities, including: (i) obtaining specific resources; (ii) receiving strategic support from important external agents; (iii) providing legitimacy to their organizations; and (iv) creating important communication channels between organizations.

The resource dependence theory understands boards of directors as mechanisms for managing external resources (Pfeffer \& Salancik, 1978), which act in reducing uncertainty (Pfeffer, 1972) and provide a reduction in transaction costs (Williamson, 1984). Therefore, from the point of view of the resource dependence theory, directors act as connections between firms and the corporate environment, minimizing the uncertainty of contin- gency factors (Hillman et al., 2000).

The premise of the resource dependence theory is that organizations, however independent they may seem, cannot ignore the relevance of external resources to their development over time. In other words, no matter how autonomous an organization is, it will always require third-party resources. Access to external resources is facilitated when corporations establish links between themselves through board members, as they tend to work in favor of common objectives (Zald, 1969). Consequently, board interlocking is regarded as a source of facilitation of access to external financial resources. Hence, companies look for board members who already perform managerial roles in other organizations with the specific aim of increasing sources of third-party financial capital (Hillman et al., 2000).

Board interlocking also favors the insertion of companies into strategic social groups. The inclusion of board members belonging to social groups or movements helps to avoid conflicting actions with social organizations that might potentially interfere with the structural plans of companies. Another benefit of board member networks involves companies' reputations in the financial market (Pfeffer \& Salancik, 1978), since corporate reputation is closely related to the resource dependence theory (Hillman et al., 2000).

Analyses of social networks also contribute to understanding the relationships between corporate practices (Kosnik, 1987; Haunschild, 1993; Davis, 1991). Kosnik (1987) investigated the relationship between the use of private share rewards (greenmail) and board interlocking. The results indicated that companies were more likely to use private rewards when professionals on their boards of directors also acted in other companies. Haunschild (1993) studied 327 American companies, covering the years from 1981 to 1990 , and found that mergers and acquisitions were directly associated with the presence of links between the boards of these companies.

Kim (2005) examined the relationship between board interlocking and performance using social networks in Korean companies and found evidence that the density of corporate networks influenced company performance. The results suggest that moderately connected companies achieve better performance, whereas very close links destroy value. The study also highlighted that the level of education of board members is positively associated with companies' financial performance.

Normally, when board members act in various organizations, they observe the actions of other board members and this leads to an important organizational learning process, specifically concerning strategic practices. In the same way that these links can generate positive results, the opposite can also occur, such as in the mimicking of the adoption of discretionary practices that lead to financial results management or to the adoption of ethically questionable behavior.

When ethical standards are involved, problems can 
arise that require the attention of outsiders, especially when board members are connected with companies with distorted or troubled shares on the stock market (Connelly \& Slyke, 2012). From this perspective, the study by Chiu, Theo and Tian (2012), involving the relationship between board interlocking and the discretionary practices of managers in 1500 American companies ranked by Standard \& Poor's (S\&P 1500) found evidence that companies were inclined to adopt discretionary results management practices when board members were linked to other companies with ratings agency classifications. On the other hand, Mindzak (2013) found that 120 Canadian companies minimized the adoption of discretionary accounting practices. Therefore, there is no consensus that board of director member networks really favor discretionary practices on the part of management. In this context, this study advances this discussion, in analyzing the relationship between board interlocking and results management in the Brazilian stock market, via the income smoothing method.

\section{CHARACTERIZATION AND METRICS OF INCOME SMOOTHING}

Income smoothing as an intentional way of cushioning or floating around some level of return is currently considered as normal in company management (Beidleman, 1973). In this way, it represents an attempt on the part of administration to reduce abnormal variations in profits. For Fudenberg and Tirole (1995), it consists of a process of manipulation of income or gains in order to make revenue streams less variable over the long run. For Michelson, Jordan-Wagner and Wootton (1988), income smoothing is a way in which managers select accounting practices in order to reduce fluctuations over financial accounting years, in accordance with generally accepted accounting principles.

Income smoothing is mainly characterized by a reduction in the variability of profits. For Scott (2012), this is the most interesting form of results management for risk adverse managers. Studies concerning this method show that accounting choices help managers to reduce variability in the compensation they receive, as well as identifying excessive fluctuations in company results over the long run. Understanding these aspects improves the accuracy of surveys carried out by market analysts.

In 1981, Norm Eckel published a paper titled "The Income Smoothing Hypotheses Revisited" in the journal Abacus, providing classifications for the different types of income smoothing (Belkaoui, 2003). For Eckel (1981), two types of smoothing exist: natural and intentional. Natural smoothing is presented as something inherent to a business and involves the result of actions taken by management that are to the detriment of the profit generating process (Belkaoui, 2003). Intentional smoothing arises from the willingness of managers to engage in certain practices with the aim of obtaining results which are aligned with their interests (Castro \& Martinez, 2009).

Ronen, Tzur and Yaari (2007) argue that intentional smoothing can be subdivided into real and artificial.

Real smoothing concerns economic choices that affect company cash flow. These stem from economic decisions taken by managers, such as reductions in training expenses, increases in advertising expenses, and sales of company assets (Martinez, 2001). Such practices are basically business conduct choices, which deliberately alter cash flows and smooth out fluctuations in results (Belkaoui, 2003). Artificial smoothing occurs with the adoption of accounting practices that transfer expenses and revenues from one accounting period to another. Such practices do not directly affect companies' current flows of profit, but do have an impact on future flows.

There are different metrics for capturing income smoothing practices. Among these, those proposed by Leuz et al. (2003) stand out. In order to meet the aims of this study, $\mathrm{EM}_{1}$ and $\mathrm{EM}_{3}$ were the only metrics used. The $\mathrm{EM}_{1}$ metric assumes that managers can disguise changes in company performance via accounting information reporting choices (Leuz et al., 2003). Such choices can be measured by the ratio between the standard deviation in operating profit $\left(\mathrm{OP}_{\mathrm{r}}\right)$ and the standard deviation in cash flow from operations (CFO), both divided by the total assets of the former period.

$$
E M_{1}=\frac{\sigma \mathrm{OPr}}{\sigma \mathrm{CFO}}
$$

In which,

$E M_{1}=$ income smoothing metric no. 1;

${ }^{\delta} \mathrm{OPr}=$ standard deviation in operating profit;

${ }^{\delta} \mathrm{CFO}=$ standard deviation in cash flow from operations.

The result of the ratio between the two variables offers evidence of the influence of the discretionary power of managers to manipulate profit, via alterations in the components of financial reports (Luiz, Nascimento \& Pereira, 2008). The lower the scores obtained, the greater the smoothing practices, since the result reveals the level by which managers reduced profit variability.

Leuz et al. (2003) also argue that managers can use their discretionary powers to distort company economic per- 
formance. The $\mathrm{EM}_{3}$ metric detects the use of discretionary practices in the reporting of financial results. The scores are obtained via the ratio between the average rate of total accruals and the absolute value of cash flows from operations.

$$
E M_{3}=\frac{|\mathrm{TA}|}{|\mathrm{CFO}|}
$$

In which,

$E M_{3}=$ income smoothing metric no. 3;

$|A T|=$ absolute value of total accruals in period $\mathrm{t}$;

$|C F O|=$ absolute value of cash flow from operations in period $t$.

The scores obtained in the $\mathrm{EM}_{3}$ metric identified discretionary practices that aimed to influence company operational performance.

\section{METHODOLOGICAL ROUTE}

The population of this study encompassed publicly traded Brazilian companies, which constitute the Bovespa Index (IBOV). The set of firms employed in the intentional sample is restricted to non-financial Brazilian companies that were components of the IBOV in May 2015 and feature the necessary information in order to estimate metrics no. 1 and no. 3 from Leuz et al. (2003), over the six years from 2009 to 2014 . The final sample was composed of 58 companies, representing $88 \%$ of those that form the IBOV.

In Figure 1, the study's predictive validation structure is presented, covering the conceptual and operational definitions for the variables analyzed, in accordance with the Libby, Bloomfield and Nelson (2002) model.

Study Structure

Association of corporate networks and income smoothing practices in publicly traded Brazilian companies

Support theory for empirical analysis

Resource Dependence Theory (PFEFFER,1972).

$\mathrm{X}$ CONCEPTUAL

Corporate networks

(board interlocking)

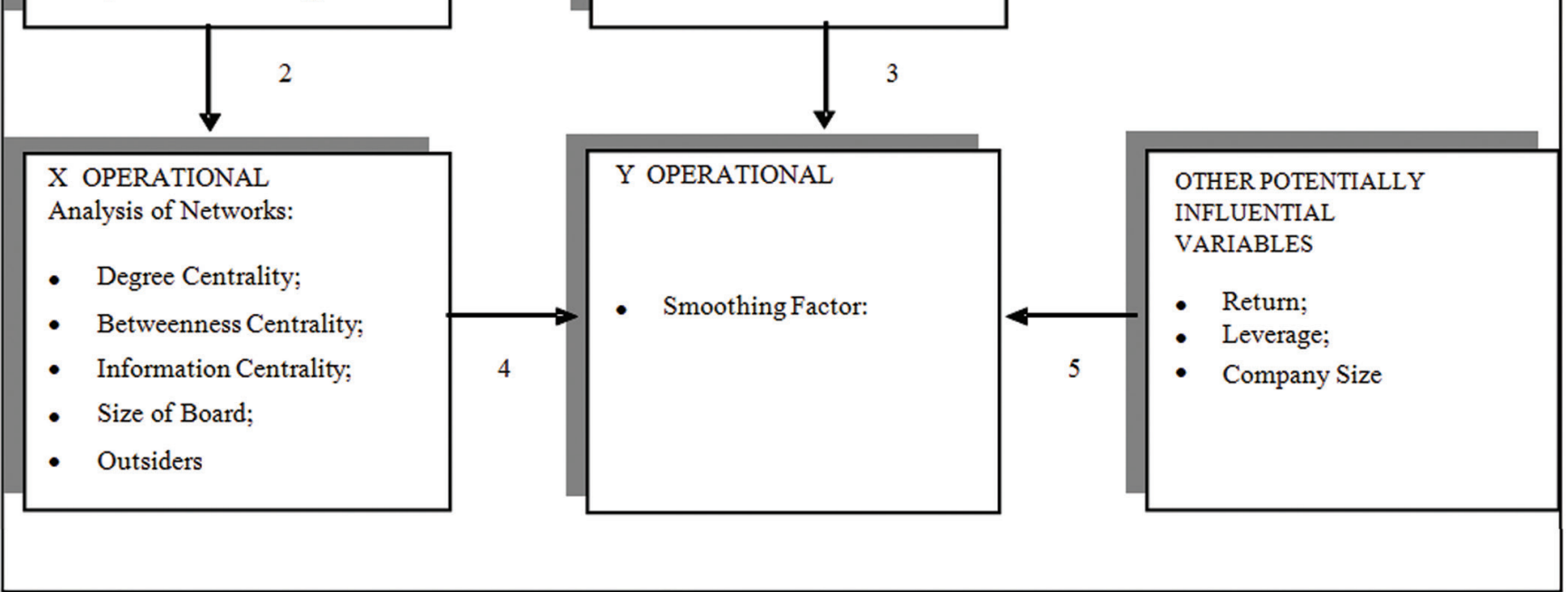

Figure 1 Predictive validity structure

Source: adapted from Libby et al. (2002) 
Based on the resource dependence theory (Pfeffer, 1972), the study proposes to explain, via network constitutive elements, the practice of income smoothing. This is measured by the smoothing factor variable, obtained by grouping the $\mathrm{EM}_{1}$ and $\mathrm{EM}_{3}$ metrics from Leuz et al. (2003), which capture types of income smoothing: $\mathrm{EM}_{1}$ detects whether managers disguise changes in company performance via financial reporting choices; and $\mathrm{EM}_{3}$ detects whether managers use their discretionary powers to distort company economic performance. The variables for the study and their operational definitions are described in Figure 2.

\begin{tabular}{|c|c|c|c|c|c|}
\hline Name of Variable & Abbreviation & Operational Definition & Form of Measurement & Expected Relationship & References \\
\hline Smoothing Factor & SF & $\begin{array}{c}\text { Metric employed to } \\
\text { identify income smoo- } \\
\text { thing practices. }\end{array}$ & 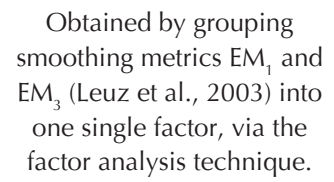 & & Leuz et al. (2003) \\
\hline Degree Centrality & Degree & $\begin{array}{l}\text { Metric used to express } \\
\text { the number of ties } \\
\text { adjoining one actor } \\
\text { with other participants } \\
\text { in the same network, in } \\
\text { other words allowing } \\
\text { for the evaluation of } \\
\text { direct links between } \\
\text { organizations. }\end{array}$ & $\begin{array}{l}\text { Expressed as a percentage } \\
\text { of the number of actors } \\
\text { (companies) present in a } \\
\text { network, minus one. }\end{array}$ & + & $\begin{array}{c}\text { Wasserman \& } \\
\text { Faust (1994); Han- } \\
\text { neman \& Riddle } \\
\text { (2005) }\end{array}$ \\
\hline Betweenness Centrality & Betweenness & $\begin{array}{l}\text { Captures the interac- } \\
\text { tions between two } \\
\text { non-adjoining actors. In } \\
\text { other words, measures } \\
\text { the indirect link betwe- } \\
\text { en companies. }\end{array}$ & $\begin{array}{l}\text { Represented by the sum of } \\
\text { the number of geodesics } \\
\text { (smallest distance that } \\
\text { unites two points) between } \\
\text { pairs of actors (companies), } \\
\text { divided by the number of } \\
\text { geodesics between organi- } \\
\text { zations that share a board } \\
\text { member. }\end{array}$ & + & $\begin{array}{l}\text { Freeman (1979); } \\
\text { Pitts (1979); } \\
\text { Mendes-da-Silva } \\
\text { (2010). }\end{array}$ \\
\hline Information Centrality & $\begin{array}{l}\text { Information cen- } \\
\text { trality }\end{array}$ & $\begin{array}{l}\text { Metric that identifies } \\
\text { the ability of board } \\
\text { members to receive } \\
\text { information, resources } \\
\text { and knowledge via his/ } \\
\text { her contacts. }\end{array}$ & $\begin{array}{c}\text { Calculated via the ratio } \\
\text { between non-redundant ties } \\
\text { and the number of links in a } \\
\text { network. }\end{array}$ & + & $\begin{array}{l}\text { Stepherson \& Zelen } \\
\text { (1989); Burt (1983). }\end{array}$ \\
\hline Size of the Board & SIZE_B & $\begin{array}{l}\text { Important variable for } \\
\text { outlining the corporate } \\
\text { governance structure. }\end{array}$ & $\begin{array}{l}\text { Natural logarithm of the } \\
\text { number of board members } \\
\text { in a company. }\end{array}$ & + & $\begin{array}{c}\text { Forbes \& Milliken } \\
\text { (1999); Silveira, } \\
\text { Barros \& Famá } \\
\text { (2003) }\end{array}$ \\
\hline Outsiders & OUTS & $\begin{array}{l}\text { Essential element for } \\
\text { good corporate gover- } \\
\text { nance practices. }\end{array}$ & $\begin{array}{l}\text { Percentage of the number of } \\
\text { board members that do not } \\
\text { perform executive roles out } \\
\text { of the total number of board } \\
\text { members in the company. }\end{array}$ & + & $\begin{array}{l}\text { Forbes \& Milliken } \\
\text { (1999); Silveira et } \\
\text { al. (2003) }\end{array}$ \\
\hline Return & $\mathrm{ROA}$ & $\begin{array}{l}\text { Verifies company } \\
\text { performance. }\end{array}$ & $\begin{array}{l}\text { Expressed as the ratio } \\
\text { between company net profit } \\
\text { and total assets. }\end{array}$ & + & $\begin{array}{l}\text { Michelson et al. } \\
\text { (1995) }\end{array}$ \\
\hline Leverage & LEV & $\begin{array}{l}\text { Verifies the level of } \\
\text { company debt. }\end{array}$ & $\begin{array}{l}\text { Represented as the sum of } \\
\text { collectables divided by the } \\
\text { total assets of an organi- } \\
\text { zation. }\end{array}$ & + & $\begin{array}{l}\text { ludícibus \& Lopes } \\
\text { (2004); Castro \& } \\
\text { Martinez (2009) }\end{array}$ \\
\hline Company Size & SIZE & $\begin{array}{l}\text { Proxy for the size of the } \\
\text { company }\end{array}$ & $\begin{array}{l}\text { Natural logarithm of the } \\
\text { total assets of the company }\end{array}$ & - & $\begin{array}{l}\text { Gu, Lee \& Rosset } \\
\text { (2005) }\end{array}$ \\
\hline
\end{tabular}


In this study, the dependent variable is represented by the smoothing factor, obtained via factor analysis constructed by grouping the $\mathrm{EM}_{1}$ and $\mathrm{EM}_{3}$ metrics from Leuz et al. (2003). The independent variables are: degree centrality, betweenness centrality, information centrality, size of the board, and outsiders. Return, leverage and company size are employed as control variables.

The data was collected via two different means. In order to identify the data concerning boards of directors, the information contained in the reference forms available on the São Paulo Stock Exchange (BM\&FBOVESPA) website was used. This information allowed for the obtainment of the variables and metrics employed in the social network analysis. Firstly, information about board members, such as full names and the companies in which they participated, was collected for each of the six years. Subsequently, with the help of the MS Excel software, square matrices that helped to identify the connections between companies were created. Following the creation of these matrices, the Ucinet 6 and Net Miner 3.0 software programs were used to obtain the social network metrics.

In order to obtain the variables that were necessary for calculating the income smoothing metrics and the control variables, the Economática database was used. To handle the data, two types of analysis were employed: (i) factor analysis, and (ii) panel data regression analysis. Factor analysis was employed due to it being considered an important statistical technique that aims to evaluate sets of variables, with the intention of unveiling existing structures that are not directly observable. Regressions were used to test the effects of the constitution of corporate social networks on income smoothing, arising from changes in company performance via financial information reporting choices $\left(\mathrm{EM}_{1}\right)$; and the use of discretionary powers to distort company economic performance $\left(\mathrm{EM}_{3}\right)$. Panel data regressions, in accordance with Adkins (2010), comprise a combination of a cross sectional group of units that are observed over time.

\section{DESCRIPTION AND ANALYSIS OF THE DATA}

First, the results of the descriptive analysis of the analyzed variables are presented, as shown in Table 1.

Table 1

Descriptive analysis of variables

\begin{tabular}{lccc}
\hline Variables & Average & $\begin{array}{c}\text { Standard } \\
\text { Deviation }\end{array}$ & VIF \\
\hline Degree & 0.428 & 0.518 & 1.574 \\
\hline Betweenness & 0.007 & 0.022 & 1.309 \\
\hline Information centrality & 0.403 & 0.226 & 1.783 \\
\hline SIZE_B & 9.196 & 2.236 & 6.075 \\
\hline OUTS & 8.429 & 2.375 & 5.582 \\
\hline ROA & 5.688 & 13.843 & 1.526 \\
\hline LEV $^{*}$ & 0.374 & 0.583 & 1.072 \\
\hline SIZE* & 34.82 & 88.33 & 1.307 \\
\hline EM $_{1}$ & 0.638 & 3.901 & 1.317 \\
\hline EM $_{3}$ & 0.943 & 4.460 & 1.695 \\
\hline
\end{tabular}

*In million reais $(\mathrm{R} \$)$.

Source: data from the study.

The centrality variables (degree, betweenness and information centrality) show that the companies analyzed exhibit, on average, a low level of direct (0.428) and indirect (0.007) links, as well as $40 \%$ non-redundant ties. In the companies analyzed, the boards of directors are composed, on average, of nine professionals. This number is much higher than the minimum of three members established in Art. 140 of Law 6,404/76. This result is also higher than the number of board members found in studies by Mendes-da-Silva in 2010 (seven), Dooley in 1969 (one) and Davis in 1991 (seven). It can be inferred that the number of board members that participate in more than one company has grown over the years due to a perception that they really do have potential to facilitate access to external resources, just as is claimed by the resource dependence theory, which views boards of directors as mechanisms for managing external resources (Pfeffer \& Salancik, 1978), and acting to reduce uncertainty (Pfeffer, 1972). Considering that companies depend more and more on third-party resources, it seems suitable that directors act as connections between firms and the corporate environment, minimizing the uncertainty of contingence factors, as is argued by Hillman et al. (2000).

The control variables used in the study show that the companies exhibit, on average, a 5.69\% return on total assets. Their capital structure is composed, predominantly, of own capital; third-party capital represents, on average, $37.4 \%$ of the sources of resources. It was also found that the companies had, on average, Total Assets of R\$34 million. With regards to the VIF (variance inflation factor), it was observed that all variables exhibited scores between 1 and 10, providing evidence of the inexistence of a colinearity problem.

Due to similar characteristics identified in the income smoothing variables captured by metrics $\mathrm{EM}_{1}$ and $\mathrm{EM}_{3}$, the use of factor analysis was chosen in order to compose a single smoothing factor. The aim behind this choice is to compose a representative income smoothing factor so that, subsequently, this variable can be inputted into the panel data regression. One of the requirements for factor analysis is a high correlation between the variables to be grouped into factors. A strong correlation was observed between the variables $\mathrm{EM}_{1}$ and $\mathrm{EM}_{3}$, of $66 \%$, with a $1 \%$ degree of significance. This suggests a sharing of common factors between the variables, which justifies the use of factor analysis. The KMO (Kaiser-Mayer-Olkin) 
and Bartlett sphericity tests were employed with the aim of confirming the results of the correlation matrix.

The KMO test, which compares the magnitude of the relationship coefficients between the variables with the magnitude of the partial correlation coefficients, exhibited a coefficient of 0.500 , making it possible to apply factor analysis. The Bartlett test exhibited a 0.00 degree of significance. Thus the null hypothesis that the correlation matrix is the identity matrix was rejected. It is therefore possible to show that a correlation between the variables exists, justifying the employment of factor analysis. Table 2 shows a description of the factors from the model and verification of the variance explained by the number of factors to be used in the model.

Table 2 Description of factors from model

\begin{tabular}{|c|c|c|c|c|c|c|}
\hline \multirow{2}{*}{ Component } & \multicolumn{3}{|c|}{ Auto-Value Total } & \multicolumn{3}{|c|}{ Extraction of Sum of Squares } \\
\hline & Total & Variance $\%$ & Cumulative \% & Total & Variance $\%$ & Cumulative $\%$ \\
\hline 1 & 1.439 & 71.972 & 71.972 & \multirow{2}{*}{1.439} & \multirow{2}{*}{71.972} & \multirow{2}{*}{71.972} \\
\hline 2 & 0.561 & 28.028 & 100.000 & & & \\
\hline
\end{tabular}

Source: data from the study.

The use of the two factors corresponds to a total explained variance of $100 \%$. However, it should be noted that using only one factor, the cumulative explained variance, it is approximately $72 \%$. Therefore, factor analysis allowed for the grouping of variables $\mathrm{EM}_{1}$ and $\mathrm{EM}_{3}$ into one single factor that will be called the "smoothing factor" in the panel data regression.

In order to apply the panel data, firstly a pooled model (ordinary least squares - OLS) was used for the constitutive social network indicators, considered explanatory variables, and the smoothing factor as the companies' income smoothing proxy. From the results, the panel diagnostic tests were carried out, with the aim of identifying the most appropriate model for the regression.
Initially, the Chow test was carried out, which verifies whether the pooled model is more appropriate, since the rejection of $\mathrm{H}_{0}$ means that the fixed effects model is more convenient. The second test, Breusch-Pagan, refuted $\mathrm{H}_{0}$, confirming that the random effects model is more suitable for the pooled model. Finally, the Hausman test was used for the option between fixed and random effects. In line with Gujurati (2006), the underlying null hypothesis to the Hausman test is that the estimators of the fixed effects model and of the error correction model are not substantially different. Thus, if the null hypothesis $\left(\mathrm{H}_{0}\right)$ is rejected, it shows that the random effects model is not appropriate given the inconsistence in the estimators, and that the employment of the fixed effects model is preferable.

\begin{tabular}{lcc} 
& Table 3 & Panel data tests \\
\hline Tests & $\boldsymbol{p}$-value \\
\hline Chow & 0.032 \\
\hline Breusch-Pagan & 0.040 \\
\hline Hausman & 0.012 \\
\hline
\end{tabular}

Source: data from the study.

From the results in Table 3, it was assumed that the use of the fixed effects model would be more consistent for the sample studied. Table 4 shows the results of the panel data regression model with fixed effects for the variable.

Table 4

Smoothing factor: panel data with fixed effects

\begin{tabular}{lccc}
\hline Significant Variables & Coefficient & Statistic t & Expected sign \\
\hline Degree & 0.3592 & $2.455^{* *}$ & + \\
\hline Betweenness & 1.6506 & 0.3841 & + \\
\hline Information centrality & -0.1303 & -0.5333 & + \\
\hline SIZE_B & 0.3703 & 0.6197 & + \\
\hline OUTS & -0.4149 & -0.615 & + \\
\hline ROA & 0.0343 & $3.136^{* * *}$ & + \\
\hline
\end{tabular}




\begin{tabular}{llcc}
\hline LEV & -0.0011 & $-4.286^{* * *}$ & - \\
\hline SIZE & -0.2167 & $-2.087^{* *}$ & - \\
\hline Constant & 0.0597 & 0.0513 & \\
\hline R-squared Adjusted & $21.83 \%$ & \\
\hline
\end{tabular}

**Significant to a degree of $5 \%$; *** Significant to a degree of $1 \%$

Source: data from the study.

It was found that the presence of direct ties, identified via the degree centrality metric, exhibits a positive and significant relationship $(B=0.3592 ; p<0.05)$ with the practice of income smoothing. This suggests that the creation of direct ties positively influences the probability of an organization managing it results. A positive and significant relationship with return $(B=0.0343$; $p$ $<0.01$ ), and a negative relationship with the debt/equity ratio $(B=-0.0011 ; \mathrm{p}<0.01)$ and company size $(\beta=$ $-0.2167 ; \mathrm{p}<0.05)$, were also noted, indicating that return, indebtedness and size of organization can have an influence in adopting the practice of income smoothing. The values found provide evidence that the discretiona- ry powers of managers over operational decisions and reporting choices can be, on average, $22 \%$ explained by the presence of direct ties between the companies.

A positive relationship of the indirect ties (betweenness) and size of board (SIZE_B) coefficients, and a negative relationship of the presence of non-redundant links and outsiders, with the practice of income smoothing, was also observed. However, the absence of significance does not allow for it to be affirmed that such constitutive elements have an influence in the adoption of income smoothing practices. Table 5 shows the estimators for income smoothing, measured by the smoothing factor.

\section{Table 5}

\begin{tabular}{|c|c|c|c|c|c|}
\hline Variables & Regression 1 & Regression 2 & Regression 3 & Regression 4 & Regression 5 \\
\hline \multirow{2}{*}{ Degree } & & 0.3175 & & & 0.3592 \\
\hline & & $2.524^{* *}$ & & & $2.455^{* *}$ \\
\hline \multirow{2}{*}{ Betweenness } & & 0.6440 & & & 1.6506 \\
\hline & & 0.1640 & & & 0.3841 \\
\hline \multirow{2}{*}{ Information Centrality } & & & 0.2132 & & -0.1303 \\
\hline & & & 0.9783 & & -0.5333 \\
\hline \multirow{2}{*}{ SIZE_B } & & & & 1.0728 & 0.3703 \\
\hline & & & & 1.616 & 0.6197 \\
\hline \multirow{2}{*}{ OUTS } & & & & -1.1982 & -0.4149 \\
\hline & & & & $-1.961 *$ & -0.615 \\
\hline \multirow{2}{*}{ ROA } & 0.0128 & 0.0352 & 0.0335 & 0.0129 & 0.0343 \\
\hline & $1.786^{*}$ & $3.289^{* * *}$ & $3.041^{* * *}$ & $1.839^{*}$ & $3.136^{* * *}$ \\
\hline \multirow{2}{*}{ LEV } & -0.0010 & -0.0011 & 0.0007 & -0.0009 & -0.0011 \\
\hline & $-3.733^{* * *}$ & $-5.555^{* * *}$ & $-4.012^{* * *}$ & $-3.261^{* * *}$ & $-4.286^{* * *}$ \\
\hline \multirow{2}{*}{ SIZE } & -0.2182 & -0.2244 & -0.2007 & -0.2005 & -0.2167 \\
\hline & $-2.545^{* *}$ & $-2.264^{* *}$ & $-2.043^{* *}$ & $-2.269^{* *}$ & $-2.087^{* *}$ \\
\hline \multirow{2}{*}{ Constant } & -0.0960 & -0.0311 & -0.6433 & 0.1104 & 0.0597 \\
\hline & -0.1117 & -0.0305 & -0.6430 & -0.1128 & 0.0513 \\
\hline R-squared & $33.20 \%$ & $48.81 \%$ & $47.20 \%$ & $34.43 \%$ & $49.04 \%$ \\
\hline R-squared Adjusted & $11.17 \%$ & $23.43 \%$ & $21.67 \%$ & $11.84 \%$ & $21.83 \%$ \\
\hline
\end{tabular}

**Significant to a degree of $5 \%$; *** Significant to a degree of $1 \%$ Source: data from the study.

The estimated coefficients in regression 1 show that the control variables leverage and company size exhibited a negative and significant relationship with the practice of smoothing, indicating that larger companies and those with a higher level of indebtedness are more inclined to adopt discretionary practices.

In regression 2, by including the variables regarding firm centrality, together with the control variables, it was 
found that the degree variable $(B=0.3175 ; p<0.05)$ exhibits statistical significance, supporting the idea that a direct link between companies influences in the adoption of income smoothing practices. Another factor that warrants mentioning are the values of the coefficients of determination, $\mathrm{R}^{2}$, varying between $11.17 \%$ and $23.43 \%$, indicating a considerable explanatory power in the independent variables. It is worth highlighting that companies belonging to the Bovespa Index are more inclined to smooth their results when their board members participate in other companies via social networks, as well as obtaining greater performance and low levels of debt.

The characteristics of the Brazilian capital market lead to think that practices such as income smoothing may be influenced by the presence of professionals acting simultaneously in two or more companies. Therefore, these conclusions point to the importance of boards of Directors, not only in controlling the decisions taken by executives, but also as important channels of resources for organizations, which is a characteristic supported by the resource dependence theory.

\section{CONCLUSIONS}

One of the methodological contributions of this study concerns the creation of an income smoothing variable (smoothing factor) based on the grouping of metrics for detecting smoothing arising from changes in company performance. This was obtained via financial reporting choices $\left(\mathrm{EM}_{1}\right)$ and the use of discretionary powers to distort company economic performance $\left(\mathrm{EM}_{3}\right)$, consistent with Leuz et al. (2003).

It was found that the companies analyzed have, on average, nine board members who participate in other boards of directors. This result for Brazilian companies shows that they have already understood the strategic importance in the configuration of corporate social networks in obtaining third-party resources. This perception is consistent with the assumption of the resource dependence theory, which underscores the potential of board member social networks in the viability of external resources. Corporate networks, in this case, act as mechanisms for managing external resources, contributing towards diminishing the uncertainties concerning the obtainment of financial resources, and in the outlining of actions that are strategically relevant for the future of companies.

The results suggest that the direct links between organizations via their board members have a positive influence in the probability of companies managing their financial results via financial information reporting choices and of the use of discretionary powers to distort economic performance. In accordance with Davis (1991), a company's position in the network influences in the adoption of similar practices. It is therefore believed that companies that have connections with other firms have privileged access to a range of information, and this increases the possibility of learning new practices and applying them in the companies belonging to their networks. The results found are consistent with those from
Kosnik (1987), Davis (1991), Mizruchi (1996), Haunschild (1993), Stearns and Mizruchi (1996), and Chiu et al. (2013), and would contradict the findings of Mindzak (2013). Regarding the links between organizations via professionals on boards of directors, it is concluded that they influence in the adoption of corporate and accounting practices in the sample analyzed.

Evidence of non-redundant ties (information centrality) was also found, and the presence of outsiders on boards tends to have a negative influence on income smoothing practices. However, the absence of statistical significance does not allow for these facts to be confirmed. It was believed that the presence of professionals acting solely on boards of directors motivated the practice of income smoothing, however this was not proven. One possible explanation could be the existence of a high number of professionals who act solely on boards, and that this is a common characteristic in the Brazilian stock market, thus making this variable of little influence.

The results provide evidence that the presence of board interlocking influences the quality of financial reporting. Companies that share board members with other organizations, where income smoothing occurs, tend to manipulate their financial results more easily. Yet, the results obtained are limited to Brazilian companies belonging to the Bovespa Index (IBOV) from 2009 to 2014. The limitations also relate to the variables selected, as well as the data analysis techniques and information available on the BM\&FBOVESPA website and the Bloomberg database. In future studies, the relationship between board interlocking and other practices used in the Brazilian capital market, such as accounting conservatism and other forms of results management, could be investigated. Possible theorical and empirical associations between the presence of board interlocking and the cost of capital for Brazilian companies could also be examined. 
Adkins, L.C. (2010). Using Gretl for principles of econometrics. Retrieved on April, 1,2013, from http://www.learneconometrics. com/gretl/ebook.pdf.

Almeida, J.E.F., Sarlo Neto, A., Bastianello, R.F., \& Adoneque, E.Z. (2012). Alguns aspectos das práticas de suavização de resultados no conservadorismo das companhias abertas listadas na BM\&FBOVESPA. Revista Contabilidade \& Finanças, 23(58), 65-75.

Au, K., Peng, M.W., \& Wang, D. (2000). Interlocking directorates, firm strategies and performance in Hong Kong: towards a research agenda. Asia Pacific Journal of Management, 17, 29-47.

Battiston, S., Weisbuch, G., \& Bonabeau, E. (2003). Decision spread in the corporate board network. Advances in Complex Systems, 6(4), 631-644.

Beidleman, C.R. (1973). Income smoothing: the role of management. The Accounting Review, 98(4), 653-667.

Belkaoui, A.R. (2003). Accounting: by principle or design? London: Praeger.

Burt, R.S. (1983). Cooptive corporate actor networks: a reconsideration of interlocking directorates involving American manufacturing. Administrative Science Quarterly, 25, 557-581.

Castro, M.A.R., \& Martinez, A.L. (2009). Income smoothing, custo de cápital de terceiros e estrutura de capital no Brasil. Revista de Administração Mackenzie, 10(6), 25-46

Chiu, P.C., Teoh, S.H.; \& Tian, F. (2013). Board interlocks and earning management contagion. The Accounting Review, 88(3); 915-944.

Connelly, B.L., \& Slyke, E.J.V. (2012). The power and peril of board interlocks. Organizational Performance, 55, 403-408.

Cox, B.A., \& Rogerson, C.M. (1985). The corporate power elite in South Africa: interlocking directorships among large enterprises. Political Geography Quarterly, 4(3), 219-234.

Davis, G.F. (1991). Agents without principles? The spread of the poison pill through the intercorporate network. Administrative Science Quarterly, 36, 583-613.

Dooley, P.C. (1969). The interlocking directorate. American Economic Review, 59, 314-323.

Eckel, N. (1981). The income smoothing hypothesis revisited. Abacus, $17(1), 28-40$.

Eisenhardt, K.M. (1989). Agency theory: an assessment and review. The Academy of Management Review, 14(1), 57-74.

Fama, E., \& Jensen, M. (1983): Separation of ownership and control Journal of Law and Economics, 26, 301-325.

Fich, E.M., \& White, L.J. (2005). Why do CEOs reciprocally sit on each other's boards? Journal of Corporate Finance, 11,175-195.

Fontes Filho, J.R., \& Leal, R.P.C. (2012). Governança corporativa: discussões sobre os conselhos em empresas no Brasil. São Paulo: Saint Paul.

Forbes, D.P., \& Milliken, F.J. (1999).Cognition and corporate governance: understanding boards of directors as strategic decision-making groups. Academy of Management Review, 24(3) 489-505.

Freeman, L.C. (1979). Centrality in social networks: conceptual clarification. Social Network, 1(3), 215-239.

Fudenberg, D., \& Tirole, J. (1995). A theory of income and dividend Smoothing based on incumbency rents. Journal of Political Economy, 103(1); 75-93.

Gales, L., \& Kesner, I. (1994). An analysis of board of director size and composition in bankrupt organizations. Journal of Business Research, 30(3), 271-282.

Gu, Z., Lee, C.W.J., \& Rosset, J.G. (2005). What determines the variability of accounting accruals? Review of Quantitative Finance and Accounting, 24, 313-334.

Gujarati, D. (2006). Econometria básica (4a ed.). São Paulo: Elsevier.

Hanneman, R.A., \& Riddle,'M. (2005). Introduction to social network methods. Riverside: University of California.

Haunschild, P.R. (1993). Interorganizational imitation: the impact of interlocks on corporate acquisition activity. Administrative Science Quarterly, 38, 564-592.

Haunschild, P.R., \& Beckman, C.M. (1998). When do interlocks matter? Alternate sources of information and interlock influence. Administrative Science Quarterly, 43, 815-844.

Hillman, A., Cannella, A., \& Paetzold, R. (2000).The resource dependence role of corporate directors: strategic adaptation of board composition in response to environmental change. Journal of Management Studies, 37, 235-256.

Hillman, A.J., \& Dalziel, T. (2003). Boards of directors and firm performance: integrating agency and resource dependence perspectives. Academy of Management Review, 28(3), 383-396.

Hung, H. (1998). A typology of the theories of the roles of governing boards. Corporate governance, 6(2), 101-111.

Iudicibus, S., \& Lopes, A.B. (2004). Teoria Avançada da Contabilidade. São Paulo: Atlas.

Johnson, J., Daily, C., \& Ellstrand, A. (1996). Boards of directors: a review and research agenda. Journal of Management, 22, 409-43.8

Kim, Y. (2005). Board network characteristics and firm performance in Korea. Corporative Governance, 13(6), 800-808.

Knowles, J.C. (1973). The Rockefeller financial group. Andover Mass: Warner Modular Publications.

Kosnik, R.D. (1987). Greenmail: a study of board performance in corporate governance. Administrative Science Quarterly, 32(2), 1.63-185.

Leuz, C., Nanda, D., \& Wysocki, P.D. (2003). Investor protection and earning management: an international comparison. Journal of Financial Economics, 69(3), 505-527.

Libby, R.; Bloomfield, R., \& Nelson, M.W. (2002). Experimental Research in Financial Accounting. Accounting, Organizations and Society, 27(8), 775-810.

Lopes, A.B., \& Tukamoto, Y.S. (2007). Contribuição ao estudo do "gerenciamento" de resultado: uma comparação entre as companhias abertas brasileiras emissoras de ADRs e nãoemissoras de ADRs. Revista de Administração, 42(1), 86-96.

Luiz, I.V., Nascimento, M., \& Pereira, L.C.S. (2008, julho). Impacto do gerenciamento de resultados no retorno anormal: estudo empírico dos resultados das empresas listadas na Bolsa de Valores de São Paulo - Bovespa. Anais do Congresso USP Controladoria.e Contabilidade, São Paulo, SP, Brasil, 8.

Lyra, I.X.M., \& Moreira, R:L. (2011). Alisamento de resultados nas empresas listadas nos níveis de governança corporativa da Bovespa. Revista Contabilidade e Controladoria, 3(2), 78-93.

Martinez, A.L. (2001). Gerenciamento dos resultados contábeis: estudo empírico das companhias abertas brasileiras. Tese de Doutorado, Faculdade de Economia, Administração e Contabilidade, Universidade de São Paulo, São Pạlo, SP, Brasil.

Martinez, A.L., \& Castro, M.A.O. (2008, junho). Income smoothing e o valor da firma. Anais do Congresso da Associação Nacional de Programas de Pós-graduação em Ciências Contábeis, Salvador, BA, Brasil, 2.

Martinez, A.L., \& Castro, M.A.O. (2009, julho). Ratings, custo de capital de terceiros e alisamento de resultados no Brasil. Anais do Encontro Brasileiro de Finanças, São Leopoldo, RS, Brașil, 9.

Mendes-da-Silva, W. (2010). Board Interlocking, desempenho financeiro e valor das empresas brasileiras listadas na Bovespa: análise sob a ótica da teoria dos grafos e de redes sociais. Tese de Doutorado Faculdade de Economia, Administração e Contabilidade, Universidade de São Paulo, São Paulo, SP, Brasil.

Michelson, S.E., Jordan-Wagner, J., \& Wootton, C.W. (1995). A market based analysis of income smoothing. Journal of Business Finance \& Accounting, 22(8), 1179-1193.

Mindzak, J. (2013, May). Interlocked Boards of Directors, Voluntary Disclosures and Earnings Quality. Proceedings of the Canadian Academic Accounting Association Annual Conference, Montreal, Quebec, Canada, 37.

Mizruchi, M.S. (1996). What do interlocks do? An analysis, critique, and assessment of research on interlocking directorates. Annual Review of Sociology, 22, 271-298.

Ornstein, M.D. (1982). Interlocking directorates in Canada: evidence from replacement patterns. Social Networks, 4, 3-25.

Pfeffer, J. (1972). Size and composition of corporate boards of directors: The organization and its environment. Administrative Science Quarterly, 17, 218-228.

Pfeffer, J., \& Salancik, G.R. (1978). The external control of organizations: a resource dependence perspective. New York: Harper \& Row.

Pitts, F.R. (1979). The medieval river trade network of Russia revisited. Social Networks, 1, 285-292.

Ronen, J., Tzur, J., \& Yaari, V. (2007). Legal insider trading, CEO's incentive, and quality of earnings. Corporate Governance and Control, 4, 210-219.

Scott, W.R. (2012). Financial accounting theory (6th ed.) Toronto Pearson Canada.

Silveira, A.M., Barros, L.A.B.C., \& Famá, R. (2003). Estrutura de governança e valor das çompanhias abertas brasileiras. Revista de 
Administração de. Empresas, 43(3), 50-64.

Stearns, L., \& Mizruchi, M. (1996). Board composition and corporate financing: the impact of financial institution representation on borrowing. Academy of Management Journal, 36, 603-618.

Stephenson, K., \& Zelen, M. (1989). Rethinking centrality: methods and examples and applications. Social Networks, 11(1), 1-37.

Tonin, J.M.F. (2012). Relação entre Income Smoothing e Ratings em companhias brasileiras de capital aberto. Dissertação de Mestrado, Universidade Federal do Paraná, Curitiba, PR, Brasil.
Wasserman, S., \& Faust, K. (1994). Social Network Analysis: Methods and Applications. Cambridge, Cambridge University Press.

Williamson, O.E. (1984).The economic institutions of capitalism: firms, markets, relational contracting. New York: Free Press.

Zajac, E.J. (1988). Interlocking directorates as an interorganizational strategy: a test of critical assumptions. The Academy of Management Journal, 31(2), 428-438.

Zald, M. (1969). The power and functions of boards of directors: a theoretical synthesis. American Journal of Sociology, 75, 97-111.

\section{Correspondence Address:}

\section{Flávio Ribeiro}

Departamento de Ciências Contábeis, Universidade Federal do Paraná

Avenida Prefeito Lothário Meissner, 632 - Campus III - CEP: 80210-070

Jardim Botânico - Curitiba - PR

Email: flavioribeiro@irati.unicentro.br 